\title{
Podobieństwa struktur zatrudnienia w sektorze przemysłowym w krajach UE-27
}

\author{
The Similarities of Employment Structures \\ in Industrial Sector in the Eu-27 Countries
}

\begin{abstract}
Streszczenie: Sektor przemysłowy jest jedną z głównych sił napędowych wzrostu gospodarczego, szczególnie w krajach rozwijających się. Pozytywna dynamika zmian w sektorze przemysłowym przyczynia się do efektów w innych sektorach gospodarki. Celem artykułu jest pogrupowanie badanych krajów UE-27 pod względem zatrudnienia w sektorze przemysłowym w celu utworzenia jednorodnych klas. Zakres czasowy analizy obejmuje 2013 rok. Wybór takiego okresu badawczego wynika z dostępności i porównywalności danych statystycznych w przekroju poszczególnych krajów Unii Europejskiej. Procedura grupowania uwzględnia wewnątrzgrupowe i międzygrupowe zróżnicowanie wybranych zmiennych diagnostycznych. W badaniu zastosowano hierarchiczne metody aglomeracji i metodę $k$-średnich. Głównymi kryteriami decydującymi o przynależności badanych krajów UE-27 do skupień są: udział zatrudnionych w produkcji i udział zatrudnionych w budownictwie. Kraje UE-15, zwłaszcza Niemcy, Wielka Brytania, Francja, Hiszpania, Włochy i osobno Polska charakteryzują się wyższymi wartościami średnich dla wybranych zmiennych diagnostycznych, czyli udziału zatrudnionych w sektorze produkcji i udziału zatrudnionych w budownictwie, w porównaniu z przeciętnymi wartościami zmiennych w grupie pozostałych krajów UE-27.
\end{abstract}

\begin{abstract}
The industrial sector is the one of key engine of economic growth especially in the developing countries. The positive dynamics of change in industrial sectors lead to effects in other areas of economy. The paper focuses on the clustering of employment in industrial sector in the EU-27 countries in order to form homogeneous clusters. The period considered is the year 2013. The choice of such a research period comes from the availability and comparability of the statistical data within the European Countries. The clustering procedure of EU countries is based on intra and inter-group differences on selected diagnostic variables. The agglomerative hierarchical clustering and k-means clustering methods were used in the paper. The main criteria for deciding on UE-27 countries belonging to clusters are the share of employment in manufacturing and the share of employment in construction. The countries of the EU-15, particularly Germany, Great Britain, France, Spain, Italy and separately Poland as well are characterized by higher values of average for selected diagnostic variables i.e. the share of employment in manufacturing and the share of employment in construction in relation to the average of variables for the remaining countries.
\end{abstract}

Słowa kluczowe: metoda $k$-średnich; metody aglomeracji; podobieństwa w grupie krajów UE-27; zatrudnienie w sektorze przemysłowym

Keywords: agglomerative hierarchical clustering method; employment in industry sector; k-means clustering; similarities in the EU-27 countries 
Otrzymano: 30 grudnia 2015

Received: 30 December 2015

Zaakceptowano: 18 lipca 2016

Accepted: 18 July 2016

Sugerowana cytacja / Suggested citation:

Wąsowicz, J. (2016). Podobieństwa struktur zatrudnienia w sektorze przemysłowym w krajach UE-27. Prace Komisji Geografii Przemysłu Polskiego Towarzystwa Geograficznego, 30(3), 33-44.

\section{WSTĘP}

Gospodarki narodowe wchodzące w skład Unii Europejskiej są podmiotami wielu badań empirycznych o charakterze komparatywnym. Badania tego typu sprowadzają się najczęściej do identyfikacji dysproporcji pomiędzy obiektami lub wskazania zmiennych decydujących o istniejących podobieństwach obiektów. W obydwu przypadkach podstawą badań jest ustalenie zestawu cech diagnostycznych. Rezultatem badań jest zakwalifikowanie poszczególnych krajów do utworzonych grup przy wykorzystaniu przyjętych miar podobieństwa. Jednocześnie podkreśla się, że skalę podobieństwa może wyrażać zwłaszcza funkcja odległości euklidesowej pomiędzy badanymi obiektami. Podobieństwo obiektów jest tym większe, im mniejsze jest zróżnicowanie wartości cech reprezentujących określone zjawisko złożone. W artykule zjawiskiem złożonym jest zatrudnienie w sektorze przemysłowym w krajach Unii Europejskiej.

Przeobrażenia strukturalne zachodzące w zatrudnieniu na świecie, zwłaszcza duży wzrost odsetka osób pracujących w sektorze usług rynkowych, znajdują się pod silnym wpływem ekspansji nowoczesnych technologii w sektorze przemysłowym (przede wszystkim systemów teleinformatycznych, w tym rozwoju internetu, nanotechnologii, biotechnologii, nowoczesnych technologii materiałowych, odnawialnych źródeł energii itp.). Powstanie wielu sekcji usługowych, a także dynamika i kierunki ich rozwoju, są ściśle uzależnione od osiągnięć naukowych i biznesowych, implementowanych w sektorze przemysłu. Postęp techniczny, m.in. poprzez nowoczesne metody wytwarzania, spowodował istotny wzrost produktywności pracy i kapitału w sektorze przemysłowym. Tempo wzrostu produktywności zostało także spotęgowane poprzez skutki postępu technicznego, ujawniające się w postaci nieuchronnych spadków zatrudnienia w niektórych sekcjach przemysłu (np. wydobywczych). Można te skutki określić mianem efektów pochodnych postępu technicznego.

Rola, jaką przemysł odgrywa w rozwoju sektora usług i całej gospodarki w warunkach globalizacji, determinuje potrzebę ciągłego badania zachodzących w nim zmian. Pożądany rozwój gospodarki w kierunku modelu usług tradycyjnych, a także nowoczesnych usług nasyconych wiedzą, wymaga rozpoznawania tendencji rozwojowych w sekcjach przemysłowych. Istniejący obszerny dorobek naukowy, eksponujący m.in. rolę i stopień przeobrażeń w sektorze usługowym w poszczególnych krajach, powinien być uzupełniany o wyniki badań nad wewnątrzsektorowymi zmianami w przemyśle.

Zakres przedmiotowy artykułu obejmuje wybrane zmienne charakteryzujące zatrudnienie w sektorze przemysłowym w grupie 27 krajów członkowskich Unii 
Europejskiej w 2013 roku. Obok kryteriów merytorycznego i formalno-statystycznego, dodatkowymi kryteriami rozstrzygającymi o kwalifikacji zmiennych diagnostycznych, a także krajów do badania, są: dostępność, porównywalność i aktualność danych statystycznych. Wobec braku danych dla gospodarki chorwackiej zdecydowano o wykluczeniu Chorwacji z grupy badanych krajów UE. Źródłem danych jest baza Eurostatu. Badanie przeprowadzono z wykorzystaniem pakietu Statistica.

Celem artykułu jest identyfikacja zmiennych opisujących podobieństwa struktury zatrudnienia w sektorze przemysłowym krajów UE-27, w tym także tych, które w największym stopniu różnicują badane obiekty. Operacjonalizacja tego celu sprowadza się do pogrupowania badanych obiektów w celu utworzenia jednorodnych klas, uwzględniających ich wewnętrzne zróżnicowanie zatrudnienia w tradycyjnych i nowoczesnych sekcjach przemysłu (wysokiej i średnio wysokiej techniki), wynagrodzeń, a także udziału w tworzeniu wartości dodanej. W badaniu wykorzystano dwie grupy metod analizy wielowymiarowej, czyli aglomeracyjne i $k$-średnich. Uzasadnieniem wyboru tych dwóch grup metod badawczych jest fakt, że wyniki zastosowanych metod aglomeracyjnych mogą być przesłanką wstępnego określenia liczby skupień w metodzie $k$-średnich.

\section{ROLA PRZEMYSŁU W KREACJI MIEJSC PRACY I WARTOŚCI DODANEJ BRUTTO NA TLE ZMIAN STRUKTURALNYCH W GOSPODARCE}

Na tle całej gospodarki sektor produkcyjny stwarza większe możliwości akumulacji kapitału, osiągania korzyści skali i nabywania nowych technologii. Jest podstawą wzrostu gospodarczego i przeobrażeń strukturalnych gospodarki narodowej (Goos, Manning, Salomons, 2009; United Nations..., 2013: 1-2). Sektor przemysłowy powoduje, że kraje rozwijające się, których celem jest utrzymanie wzrostu gospodarczego przy jednoczesnej kreacji miejsc pracy, uzyskują możliwość nie tylko zrównoważenia gospodarki dzięki sekcjom generującym wyższą wartość dodaną brutto, ale też stworzenia bazy do zatrudnienia osób charakteryzujących się produktywnością wyższą od przeciętnej. W porównaniu z sektorem przemysłowym słabością sektora usługowego jest to, że przyczynia się on do realizacji jedynie pierwszego z tych celów (United Nations..., 2013: 1-2). W krajach rozwiniętych przemysł pozostaje głównym źródłem akumulacji kapitału oraz źródłem wiedzy i jest niezbędny do utrzymania wzrostu gospodarczego oraz - w pewnym stopniu - do tworzenia miejsc pracy.

W krajach rozwiniętych i w większości krajów rozwijających się główne przesunięcia zasobów pracy dokonały się pomiędzy poszczególnymi sektorami gospodarczymi. Jeśli uwzględnić zagregowane dane dotyczące sytuacji na świecie, w latach 1991-2015 odsetek osób zatrudnionych w rolnictwie zmniejszył się z 44,5\% do około 30\%. Wydaje się, że jedną z najistotniejszych determinant tych przeobrażeń jest dynamiczny wzrost produktywności pracy w rolnictwie (mechanizacja, komputerowo sterowana irygacja upraw, stosowanie środków ochrony roślin uprawnych, efekty skali produkcji). Prognozy Międzynarodowej Organizacji Pracy (MOP) wskazują, że do 2018 roku na świecie udział osób zatrudnionych w rolnictwie zmniejszy się przeciętnie do poziomu poniżej 30\% (International Labour Organization, 2014: 96-97; 2015). W tych samych latach (1991-2105) zatrudnienie w sektorze przemysłowym 
wzrosło z 21,7\% do 23,4\% i wykazuje dalszą tendencję wzrostową. Największy napływ zasobów pracy pochodzących z innych sektorów i w rezultacie największy wzrost udziału zatrudnionych ukształtował się w sektorze usług (z 33,8\% w 1991 roku do 45,8\% w 2015 roku).

W statystykach MOP kraje rozwinięte i kraje członkowskie Unii Europejskiej ujęte są w jedno skupienie. W latach 1991-2015 w tej grupie dokonały się głębokie przeobrażenia struktur zatrudnienia, które stanowią egzemplifikację faz absorpcji zasobów pracy występujących w poszczególnych etapach rozwoju gospodarczego. W krajach rozwiniętych i wchodzących w skład UE odsetek zatrudnionych w rolnictwie zmniejszył się z 6,9\% w 1991 roku do 3,5\% w 2015 roku, udział zatrudnionych w przemyśle także się zmniejszył (z 31\% do 22,4\%), a w usługach wzrósł (z 62\% do 74,2\%). Prognozy opracowane przez MOP wskazują, że do 2018 roku nastąpi dalszy spadek zatrudnienia w rolnictwie (do poziomu 3,2\%), dalszy niewielki spadek zatrudnienia w przemyśle (do poziomu 22,2\%) i dalszy niewielki wzrost zatrudnienia w usługach (do poziomu 74,6\%).

Powyższe dane wskazują, że istnieją duże dysproporcje w kierunkach i skali zmian zatrudnienia w sektorze przemysłowym, zachodzących w poszczególnych regionach świata i w rezultacie tego w poszczególnych krajach. Zmiany te eksponują mechanizm przesunięć potencjału produkcyjnego z krajów rozwiniętych (np. zachodniej Europy, USA), o wyższym dochodzie narodowym, do krajów rozwijających się (np. krajów Europy Środkowo-Wschodniej, Chin, Indii, Brazylii, Indonezji), zapewniających dostęp do tańszych i jednocześnie wykwalifikowanych zasobów pracy (Blinder, 2007a; Staritz, 2010). Egzemplifikację powyższego mechanizmu stanowią dwa sektory przemysłowe o największej chłonności zatrudnieniowej na świecie, czyli produkcja samochodów, części i podzespołów (high-tech) oraz produkcja tekstyliów i odzieży (low-tech), choć powody i tempo przenoszenia zakładów wytwarzających te dobra są zróżnicowane. Najważniejszą przesłanką przenoszenia produkcji motoryzacyjnej jest dążenie do zdobycia pozycji na dużych rynkach wschodzących a produkcji odzieży i tekstyliów - tania siła robocza (Staritz, 2010).

Skala i tempo przemian strukturalnych w zatrudnieniu mają ważne implikacje dla wzrostu gospodarczego poszczególnych krajów. Analiza danych wskazuje, że w krajach dokonujących szybkiej transformacji sektorowej na początkowych etapach wzrostu i rozwoju gospodarczego, istnieje relatywnie duże ryzyko wystąpienia „pułapki średniego dochodu" (Goos, Manning, Salomons, 2009; International Labour Organization, 2014: 28-30). W rezultacie kraje te nie są potem zdolne do osiągania przyrostów wydajności i wprowadzania innowacji, które są determinantami wyższego poziomu dochodu narodowego.

Spowolnienie przekształceń strukturalnych obserwowane w wielu gospodarkach wschodzących ma wpływ na dynamikę wzrostu produkcji w tych krajach (International Labour Organization, 2013). Tempo przepływów zasobów pracy z rolnictwa do sekcji o wyższych wartościach dodanych nie jest tak wysokie, jak to miało miejsce w przeszłości. Stymulowanie międzysektorowej mobilności pracowników oraz spadek zatrudnienia w rolnictwie stanowią pewien cel ciągły polityki makroekonomicznej państwa. W przeszłości wiele krajów na świecie dynamizowało swój wzrost gospodarczy 
poprzez migracje pracowników pierwotnie zatrudnionych w rolnictwie na terenach wiejskich do obszarów miejskich, gdzie podejmowali pracę w przemyśle i usługach o relatywnie wysokiej produktywności (Blinder, 2007b; International Labour Organization, 2013).

Pierwotne źródła wzrostu gospodarczego w postaci poprawy dostępności czynników produkcji (pracy i kapitału) w wielu krajach uległy wyczerpaniu. Absorpcja zasobów pracy w poszczególnych sektorach gospodarki również w okresach spowolnienia gospodarczego jest kształtowana pod wpływem wielu czynników. Jako jedną z głównych przesłanek przesunięć zasobów pracy z sektorów rolniczego i produkcyjnego do sektora usługowego uznaje się dysproporcje pomiędzy poziomami i tempami zmian wydajności pracy w poszczególnych sektorach gospodarki (Appelbaum, Schettkat, 1999: 387-398; D’Agostino, Serafini, Ward-Warmedinger, 2006: 10). W rezultacie warunkiem utrzymania relatywnie wysokich stóp wzrostu gospodarczego w długim okresie jest poprawa wykorzystania nakładów oraz wzrost ogólnej produktywności pracy i kapitału. Jeśli skonfrontować te ustalenia teoretyczne z faktami makroekonomicznymi, to okazuje się, że w większości krajów europejskich (dotyczy to także Polski) największy wkład do wzrostu ogólnej produktywności pracy ma sektor przemysłowy (Eurostat, 2015). Do innych ważnych czynników decydujących o przesunięciach zasobów pracy pomiędzy trzema sektorami gospodarki zalicza się wpływ międzynarodowego podziału pracy oraz zmiany współczynników dochodowej elastyczności popytu w kategorii produktów i usług (Katouzian, 1970: 362-382).

\section{STATYCZNY OBRAZ PODOBIEŃSTW KRAJÓW UE-27 W ASPEKCIE ZATRUDNIENIA W SEKTORZE PRZEMYSŁOWYM}

W badaniu wykorzystano metody hierarchiczne analizy wielowymiarowej (aglomeracji) i metodę $k$-średnich. Na podstawie kryterium merytorycznego i statystycznego (Balcerowicz-Szkutnik, Sojka, 2011: 10 i nast.; Mojena, 1997: 359 i nast.), w pierwszym etapie badań, do zbioru cech diagnostycznych zakwalifikowano ostatecznie pięć zmiennych (stymulant) charakteryzujących zatrudnienie w sektorze przemysłowym w grupie krajów UE-27 w 2013 roku:

$X_{1}$ - odsetek zatrudnionych w produkcji (UE-27 = 100) - [stymulanta],

$X_{2}$ - odsetek zatrudnionych w budownictwie (UE-27 = 100) - [stymulanta],

$X_{3}$ - wynagrodzenia w przemyśle (z wyłączeniem budownictwa) według parytetu

siły nabywczej (UE-27 = 100) - [stymulanta],

$X_{4}$ - wartość dodana brutto w przemyśle (UE-27 = 100) - [stymulanta],

$X_{5}$ - zatrudnienie w sektorze produkcyjnym wysokiej i średnio wysokiej techniki

(\% ogółu zatrudnionych) - [stymulanta].

Współczynniki zmienności rozkładów wszystkich powyższych cech przewyższają wartość 0,10. Wybór okresu badawczego (2013 rok) był podporządkowany kryterium aktualności danych i jednocześnie uwzględniał ich kompletność w całej grupie badanych krajów UE. Z badania wykluczono gospodarkę Chorwacji ze względu na brak danych o wartościach wymienionych zmiennych diagnostycznych. Pierwotny zestaw zmiennych obejmował przede wszystkim udział wynagrodzeń w przemyśle w PKB 
poszczególnych krajów oraz odsetek zatrudnionych w sekcjach produkcyjnych wysokiej i średniej techniki (zatrudnienie ogółem w danym kraju = 100). W trakcie badania uzyskano niesatysfakcjonujące wartości miar zróżnicowania międzygrupowego i wewnątrzgrupowego, a także niesatysfakcjonujące wartości testu $F$, weryfikującego statystyczną istotność obydwu rozpatrywanych zmiennych diagnostycznych. Wartość $p$ dla zmiennej „udział wynagrodzeń w przemyśle w PKB” wyniosła 0,380, a dla zmiennej „odsetek zatrudnionych w sekcjach produkcyjnych wysokiej i średniej techniki” $p=$ 0,536 . Ostateczny zestaw przyjętych zmiennych pozwolił wyeliminować istotną część tych problemów (vide wyniki uzyskane metodą $k$-średnich, zaprezentowane w dalszej części artykułu).

W celu pozbycia się miana zmiennych i ujednolicenia rzędu ich wielkości przeprowadzono normalizację cech diagnostycznych, wykorzystując standaryzację stymulant:

$$
Z_{i j}=\frac{x_{i j}-\bar{x}_{j}}{S\left(x_{j}\right)} \quad i=1,2, \ldots, n ; j=1,2, \ldots, m
$$

Odległości pomiędzy skupieniami oceniono na podstawie liniowego wykresu ilustrującego odległość euklidesową pomiędzy skupieniami państw UE-27 w momencie, gdy były one łączone (ryc. 1). Miejsce na wykresie przebiegu aglomeracji, w którym widoczne jest spłaszczenie, oznacza, że skupienia są odległe. W sensie formalno-statystycznym miejsce podziału dendrogramu należy umieścić po dwudziestym siódmym kroku.

Ryc. 1. Wykres przebiegu aglomeracji dla metody pełnego wiązania

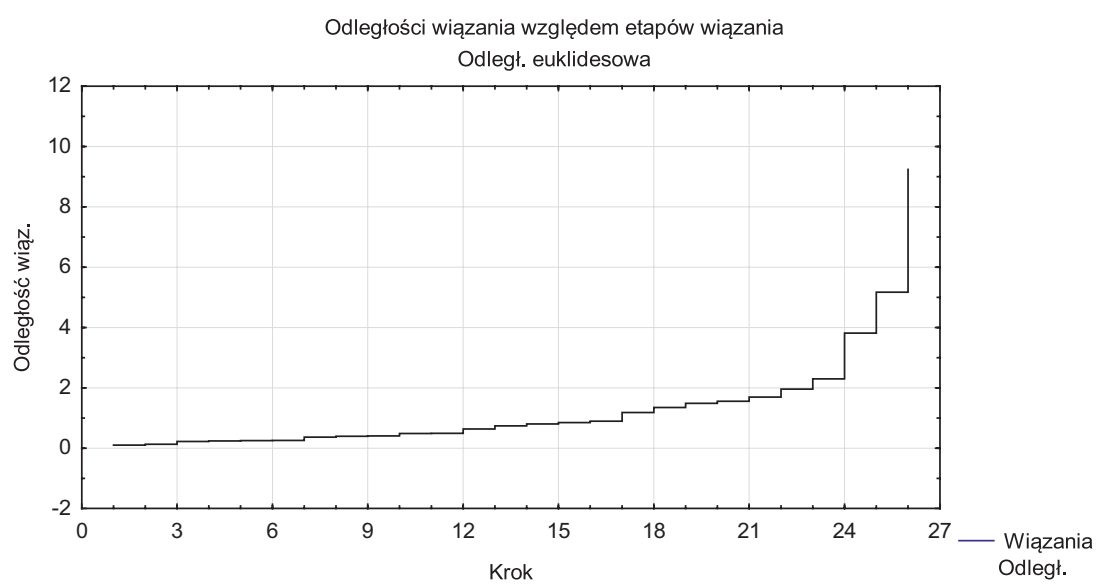

Źródło: oszacowanie na podstawie Eurostatu (2015)

W grupowaniu państw członkowskich UE-27 wykorzystano także wykres przebiegu aglomeracji reprezentujący wyniki uzyskane metodą Warda (ryc. 2). Miejsce podziału drzewa hierarchicznego znajduje się po dwudziestym siódmym kroku. Wyniki wiązania metodą Warda są zbieżne z wynikami uzyskanymi w metodzie pełnego wiązania. 
Ryc. 2. Wykres przebiegu aglomeracji dla metody Warda

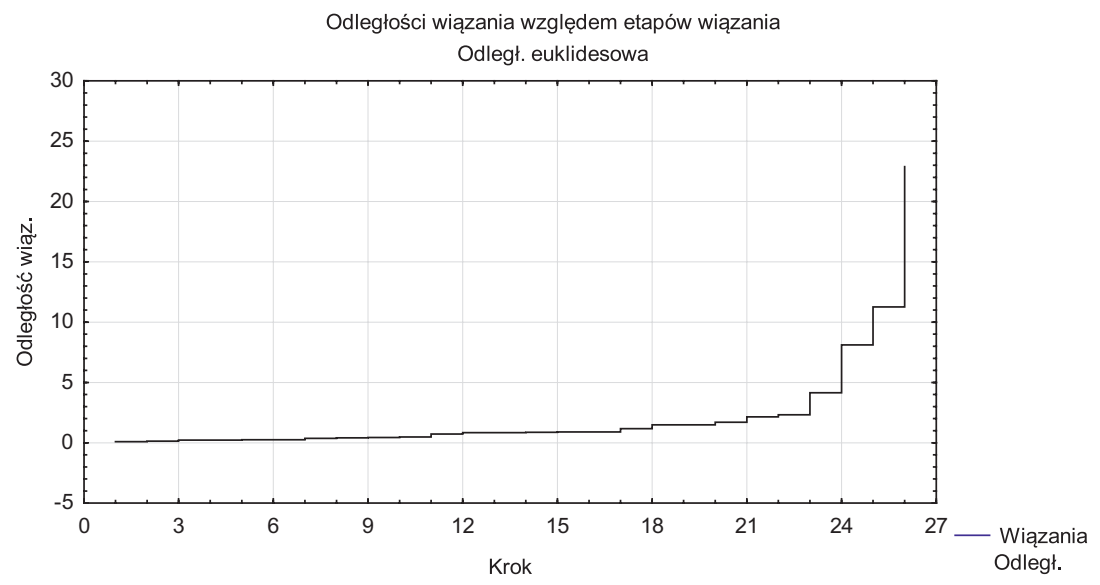

Źródło: oszacowanie na podstawie Eurostatu (2015)

Na podstawie wyników zastosowanych metod hierarchicznych podziału dendrogramów stwierdzono, że najlepszym rozwiązaniem jest przyjęcie dwóch grup państw UE-27 (ryc. 3, 4). W przypadku metody pełnego wiązania dokonano podziału na dwa następujące skupienia (ryc. 3):

- skupienie 1: Austria, Belgia, Bułgaria, Chorwacja, Cypr, Czechy, Dania, Estonia, Finlandia, Francja, Grecja, Hiszpania, Holandia, Irlandia, Litwa, Luksemburg, Łotwa, Malta, Polska, Portugalia, Rumunia, Słowacja, Słowenia, Szwecja, Węgry, Włochy, Wielka Brytania,

- skupienie 2: Niemcy.

Ryc. 3. Dendrogram uzyskany metodą pełnego wiązania

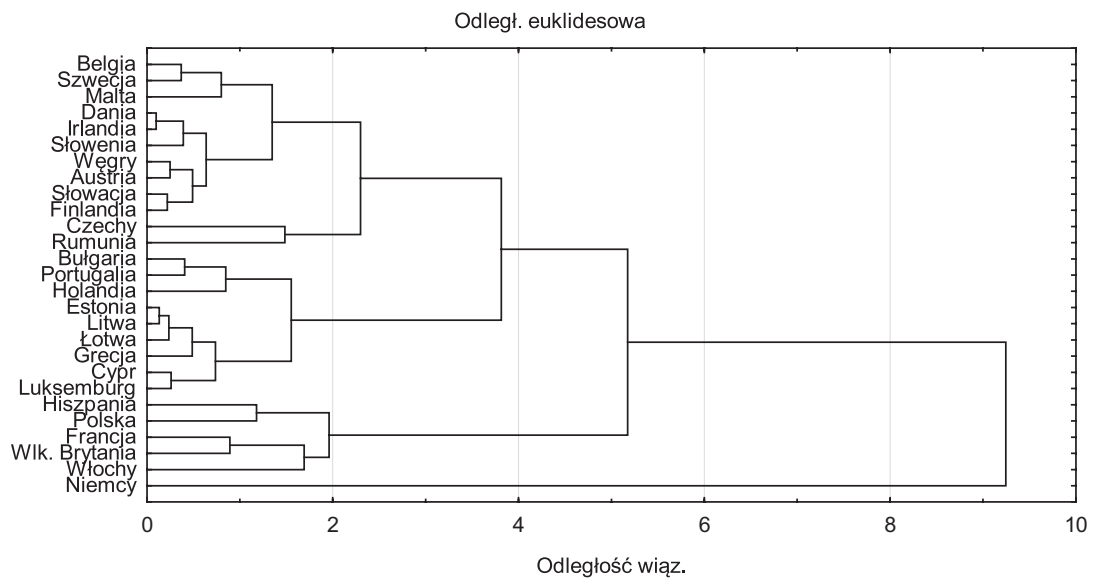

Źródło: oszacowanie na podstawie Eurostatu (2015) 
Wydaje się, że otrzymane dwie grupy krajów, w tym skupienie jednoelementowe utworzone przez gospodarkę Niemiec, dość dobrze odzwierciedlają faktyczne podobieństwa w aspekcie zatrudnienia w przemyśle. Niemcy są gospodarką wiodącą pod tym względem w Unii Europejskiej. Skupienie obejmujące pozostałe kraje członkowskie UE jest istotnie zróżnicowane względem zakresie zatrudnienia w przemyśle.

Zastosowana metoda Warda pozwoliła na utworzenie dwóch grup badanych państw (ryc. 4):

- grupa 1: Austria, Belgia, Bułgaria, Chorwacja, Cypr, Czechy, Dania, Estonia, Finlandia, Grecja, Holandia, Irlandia, Litwa, Luksemburg, Łotwa, Malta, Portugalia, Rumunia, Słowacja, Słowenia, Szwecja, Węgry,

- grupa 2: Francja, Hiszpania, Niemcy, Polska, Wielka Brytania, Włochy.

Ryc. 4. Dendrogram uzyskany metodą Warda

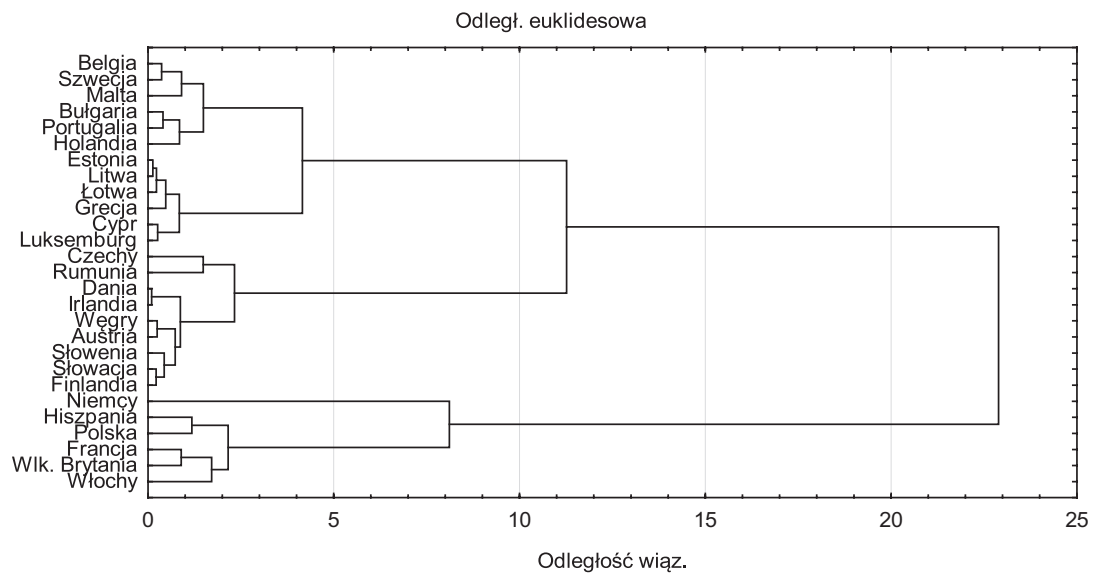

Źródło: oszacowanie na podstawie Eurostatu (2015)

Polska jest jedynym krajem Europy Środkowo-Wschodniej, który został zakwalifikowany do grupy drugiej, razem z krajami wysoko rozwiniętymi, takimi jak Niemcy, Wielka Brytania, Francja, Włochy.

W świetle tych ustaleń istotne jest pytanie badawcze o zmienne diagnostyczne, które w największym stopniu zdeterminowały przynależność gospodarek do poszczególnych skupień.

W celu określenia wstępnej liczby skupień w metodzie $k$-średnich wykorzystano wyniki uzyskane przy pomocy metod podziału drzew hierarchicznych pełnego wiązania i Warda. Dla potrzeb analizy ustalono liczbę dwóch skupień i dziesięciu iteracji. Oszacowania zweryfikowały trafność przyjętych założeń. Odległości pomiędzy państwami zostały posortowane, a na początkowe centra skupień wybrano państwa przy stałych interwałach. Zastosowana metoda $k$-średnich zapewniła wyłonienie dwóch skupień w ramach badanych krajów UE-27 oraz ich odległości od środków skupień (tab. 1). 
Tab. 1. Elementy skupień i odległości poszczególnych państw od środków skupień

\begin{tabular}{|l|c|}
\hline $\begin{array}{c}\text { Elementy skupienia nr } 1 \\
6 \text { przypadków }\end{array}$ & Odległości \\
\hline Niemcy & 014730 \\
\hline Hiszpania & 0,820601 \\
\hline Francja & 0,437311 \\
\hline Włochy & 0,326661 \\
\hline Polska & 0,718342 \\
\hline Wlk. Brytania & 0,502465 \\
\hline
\end{tabular}

\begin{tabular}{|l|l|}
\hline $\begin{array}{c}\text { Elementy skupienia nr } 2 \\
\text { 21 przypadków }\end{array}$ & Odległości \\
\hline Belgia & 0,171851 \\
\hline Bułgaria & 0,224282 \\
\hline Czechy & 0,945358 \\
\hline Dania & 0,298506 \\
\hline Estonia & 0,516080 \\
\hline Irlandia & 0,305542 \\
\hline Grecja & 0,579737 \\
\hline Cypr & 0,653990 \\
\hline Łotwa & 0,440762 \\
\hline Litwa & 0,517756 \\
\hline Luksemburg & 0,762558 \\
\hline Węgry & 0,416654 \\
\hline Malta & 0,229222 \\
\hline Holandia & 0,416195 \\
\hline Austria & 0,445705 \\
\hline Portugalia & 0,361288 \\
\hline Rumunia & 0,566367 \\
\hline Słowenia & 0,452791 \\
\hline Słowacja & 0,559809 \\
\hline Finlandia & 0,483754 \\
\hline Szwecja & 0,137950 \\
\hline
\end{tabular}

Źródło: oszacowanie na podstawie Eurostatu (2015)

Wyniki metody $k$-średnich zaprezentowane w tab. 1 są zbieżne z wynikami uzyskanymi metodą Warda (ryc. 4), co może świadczyć o właściwym doborze zmiennych opisujących zatrudnienie w przemyśle w badanych krajach. Za ich pośrednictwem zweryfikowano tezę, że gospodarka Niemiec, włączona do jednego skupienia z Polską, Wielką Brytanią, Francją, Włochami i Hiszpanią, istotnie różni się pod względem zatrudnienia w przemyśle od pozostałych krajów. Świadczy o tym relatywnie duża odległość euklidesowa Niemiec od środka pierwszego skupienia (tab. 1).

Już pobieżna ocena wartości zmiennych diagnostycznych wskazała, że Niemcy są europejskim liderem pod względem efektów polityki przemysłowej, w tym także polityki innowacji. Jeśli uwzględnić wszystkie wyniki uzyskane metodą $k$-średnich (obydwa wyłonione skupienia), to okazuje się, że Niemcy są jedynym krajem, w którym takie zmienne, jak: zatrudnienie w przemyśle (produkcja i budownictwo), wartość dodana brutto przemysłu, wynagrodzenia w sektorze przemysłowym, zatrudnienie w sekcjach wysokiej i średnio wysokiej techniki, istotnie różnicują ich pozycję względem pozostałych krajów UE-27. Na tym tle pozytywnie kształtuje się także gospodarka czeska. Odległość tego kraju od środka w skupieniu drugim jest największa, co może świadczyć o jego relatywnie dobrej sytuacji zatrudnienia w przemyśle. 
Tab. 2. Analiza wariancji zestandaryzowanych zmiennych

\begin{tabular}{|c|c|c|c|c|c|c|}
\hline \multirow{2}{*}{ Zmienna } & \multicolumn{7}{|c|}{ Analiza wariancji } & Istotn. $\mathrm{p}$ \\
\cline { 2 - 7 } & Między SS & $\mathrm{df}$ & Wewn. SS & $\mathrm{df}$ & $\mathrm{F}$ & 25 \\
\hline $\mathrm{Z1}$ & 19,25025 & 1 & 6,74975 & 25 & 71,2998 & 0,00000 \\
\hline Z2 & 22,60095 & 1 & 3,39905 & 25 & 166,2301 & 0,000000 \\
\hline Z3 & 15,21067 & 1 & 10,78933 & 25 & 35,2447 & 0,000003 \\
\hline Z4 & 16,91117 & 1 & 9,08883 & 25 & 46,5164 & 0,000000 \\
\hline Z5 & 1,77848 & 1 & 24,22152 & 25 & 1,8353 & 0,187581 \\
\hline
\end{tabular}

Źródło: oszacowanie na podstawie Eurostatu (2015)

Weryfikacja wyników badania uzyskanych metodą $k$-średnich wskazuje m.in., że zmienne diagnostyczne $Z_{1}, Z_{2}, Z_{3}$ i $Z_{4}$ są statystycznie istotne (przy poziomie istotności 0,01 ). Problem $z$ poziomem statystycznej istotności pojawił się jedynie w przypadku zmiennej diagnostycznej $Z_{5}(p=0,1876)$. Przypomnijmy, że włączanie do badania kolejnych zmiennych opisujących zatrudnienie w sekcjach produkcyjnych high-tech i medium high-tech doprowadziło do uzyskania wartości $p$ na poziomie wskazanym w tab. 2 . Jednocześnie wydaje się, że współczynnik ufności równy wartości 0,80 nie powinien eliminować tej jednej zmiennej. Oszacowane wartości testu $F$ pozwalają stwierdzić, że głównymi kryteriami różnicującymi sytuację krajów UE-27 pod względem zatrudnienia w przemyśle (produkcja i budownictwo), wartości dodanej brutto przemysłu, wynagrodzeń w przemyśle, zatrudnienia w sekcjach wysokiej i średniowysokiej techniki, decydującymi o ich przynależności do skupień, są zmienne $Z_{2}$ i $Z_{1}$ (kolejność według poziomu statystycznej istotności). Zmienna $Z_{5}$ w największym stopniu przyczyniła się do zróżnicowania wewnątrzgrupowego w skupieniach, choć należy pamiętać o relatywnie wysokim prawdopodobieństwie popełnienia błędu obciążającego ten wniosek (wartość $p$ ).

Ryc. 5. Średnie wartości zmiennych w utworzonych skupieniach państw

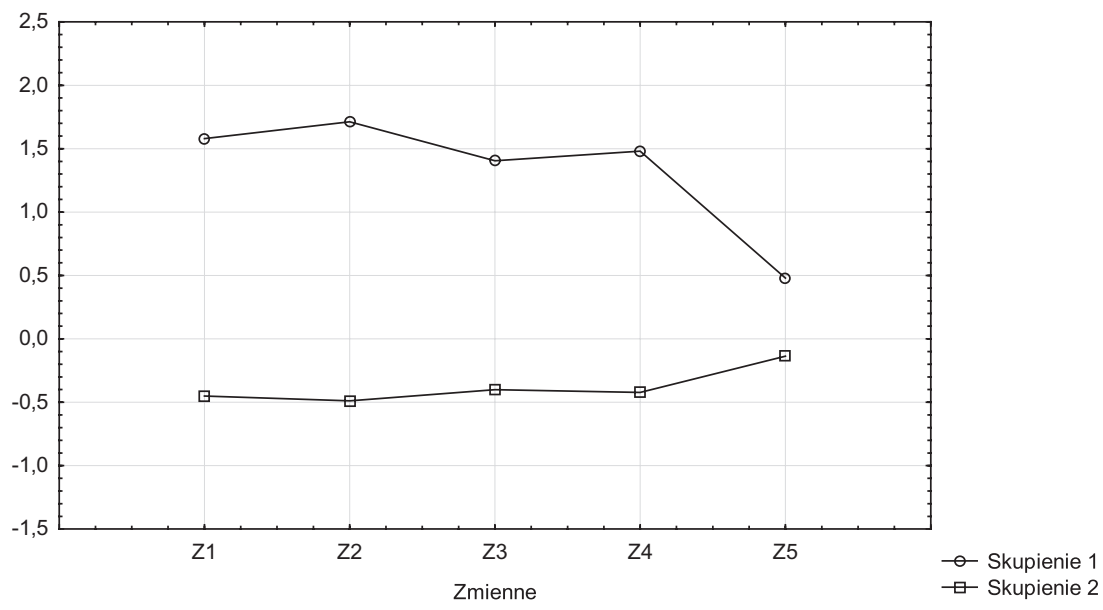

Źródło: oszacowanie na podstawie Eurostatu (2015) 
Charakterystykami dopełniającymi proces weryfikacji wyników badania statystycznego są wartości średnie obydwu skupień (ryc. 5). Skupienie pierwsze charakteryzuje się wyższymi średnimi wartościami zmiennych diagnostycznych. Największe różnice pomiędzy dwoma skupieniami krajów UE-27 występują w przypadku zmiennych $Z_{2}$ (odsetek zatrudnionych w budownictwie) i $Z_{1}$ (odsetek zatrudnionych w produkcji). Oszacowane wartości średnie korespondują z uzyskanymi wynikami analizy wariancji międzygrupowych i wewnątrzgrupowych poszczególnych zmiennych. Jednocześnie najmniejsze różnice pomiędzy skupieniami gospodarek UE-27 występują w przypadku zmiennej $Z_{5}$ (zatrudnienie w sekcjach wysokiej techniki).

\section{ZAKOŃCZENIE}

Wyniki badania uzyskane z zastosowaniem metod aglomeracyjnych i metody niehierarchicznej pozwoliły na sformułowanie wniosków odnoszących się do problemu badawczego:

- w większości krajów europejskich, w tym także w Polsce, sektor przemysłowy generuje największy, spośród pozostałych sektorów, wkład do wzrostu ogólnej produktywności pracy,

- głównymi kryteriami różnicującymi sytuację poszczególnych krajów UE-27 w zakresie zatrudnienia w przemyśle są: udział zatrudnionych w produkcji i udział zatrudnionych w budownictwie,

- zmienną mającą najmniejszy wpływ na przynależność do skupień jest odsetek osób zatrudnionych w sekcjach produkcji o wysokiej i średnio wysokiej technice,

- kraje objęte badaniem charakteryzują się dużym zróżnicowaniem zatrudnienia w sektorze przemysłowym,

- uwzględnione w badaniu kryteria ilościowe wskazują, że zdecydowanym liderem pod względem zatrudnienia w przemyśle (w tym także w sekcjach o wysokiej produktywności), wartości dodanej brutto i wynagrodzeń jest gospodarka Niemiec,

- sytuację gospodarki niemieckiej, w porównaniu z innymi krajami UE-27, bardzo różnicuje zatrudnienie w sekcjach wysokiej i średniowysokiej techniki; wydaje się, że jest to skutkiem konsekwentnie realizowanej polityki przemysłowej w tym kraju, obejmującej zwłaszcza relatywnie wysokie nakłady na innowacje produktowe i procesowe, pochodzące zarówno ze źródeł publicznych, jak i komercyjnych,

- w związku z globalną presją na wprowadzanie innowacji produktowych i procesowych, dalsze badania empiryczne dotyczące dysproporcji pomiędzy krajami UE w zakresie zatrudnienia w sektorze przemysłowym powinny koncentrować się na wewnątrzsektorowych przepływach zasobów pracy; szczególne zainteresowanie badaczy powinno być ukierunkowane na sekcje produkcyjne wysokiej techniki i ich wpływ na kreację miejsc pracy w sektorze usługowym.

\section{Literatura}

\section{References}

Appelbaum, E., Schettkat, R. (1999). Are Prices Unimportant? The Changing Structure of the Industrialized Economies. Journal of Post Keynesian Economics, 21(3), 387-398.

Balcerowicz-Szkutnik, M., Sojka, E. (2011). Pokolenie 50+ na europejskim rynku pracy - podsumowanie poszczególnych etapów badań. Katowice: Uniwersytet Ekonomiczny w Katowicach, 9-20. 
Blinder, A.S. (2007a). How Many U.S. Jobs Might Be Offshorable? CEPS Working Paper, 142, 1-45. Blinder, A.S. (2007b). Offshoring: Big Deal, orBusiness as Usual? CEPS Working Paper, 149, 1-39. D'Agostino, A., Serafini, R., Ward-Warmedinger, M. (2006). Sectoral Explanations of Employment in Europe. The Role of Services. Working Paper Series, 625, 3-59.

Goos, M., Manning, A., Salomons, A. (2009). Job polarization in Europe. The American Economic Review, 99(2), 58-63.

Eurostat (2015, 20 listopada). Pozyskano z http://ec.europa.eu/eurostat (Statistic Database: Data Navigation Tree)

International Labour Organization (2013). Global Employment Trends 2013. Recovering from a second jobs dip. Geneva, 3-170.

International Labour Organization (2014). Global Employment Trends 2014. Risk of a jobless recovery? Geneva, 3-126.

International Labour Organization (2015, 20 listopada). Pozyskano z http://www.ilo.org

Katouzian, M.A. (1970). The Development of the Service Sector: A New Approach. Oxford Economic Papers, 22(3), 362-382.

Mojena, R. (1997). Hierarchical Grouping Methods and Stopping Rules: An Evaluation. Computer Journal, 20(4), 359-363.

Staritz, C. (2010) (2016, 18 lipca). Making the Cut? Low-Income Countries and the Global Clothing Value Chain in a Post-quota and Post-crisis World. The World Bank. Pozyskano z http://documents.worldbank.org/curated/en/2011/01/13362258/making-cut-low-income-countries-global-clothing-value-chain-post-quota-post-crisis world

United Nations Industrial Development Organization (2013). Industrial Development Report 2013, Sustaining Employment Growth: The Role of Manufacturing and Structural Change. Vienna, 3-246.

Jarosław Wąsowicz, dr, Uniwersytet Ekonomiczny w Katowicach, Wydział Ekonomii, Katedra Analiz i Prognozowania Rynku Pracy. Zainteresowania naukowe autora koncentrują się wokół zagadnień ekonomicznych, ze szczególnym uwzględnieniem problemów rynku pracy, w tym mechanizmów kreacji miejsc pracy w gospodarce, elastyczności rynku pracy, instrumentów polityki pieniężnej, wybranych metod ilościowych w badaniach rynku pracy. Dorobek naukowy autora obejmuje kilkadziesiąt publikacji.

Jarosław Wąsowicz, Ph.D., Assistant Professor, University of Economics in Katowice, Faculty of Economics, Department of Labour Market Research and Forecasting. The author's research interests focus mainly on issues related to economy, especially labour market economy In his research work he examines the issues of job creation mechanism, labour market flexibility, monetary policy instruments, selected statistical methods in labour market research. He is the author of several doyen publications.

\title{
Adres/address:
}

\author{
Uniwersytet Ekonomiczny w Katowicach \\ Wydział Ekonomii \\ Katedra Analiz i Prognozowania Rynku Pracy \\ ul. Bogucicka 14, 40-287 Katowice, Polska \\ e-mail: jaroslaw.wasowicz@ue.katowice.pl
}

